\title{
A Single Dominant Locus, Ren4, Confers Rapid Non-Race-Specific Resistance to Grapevine Powdery Mildew
}

\author{
David W. Ramming, Franka Gabler, Joe Smilanick, Molly Cadle-Davidson, \\ Paola Barba, Siraprapa Mahanil, and Lance Cadle-Davidson
}

First, second, and third authors: U.S. Department of Agriculture-Agricultural Research Service (USDA-ARS), San Joaquin Valley Agricultural Sciences Center, Parlier, CA 93648-9757; fourth, sixth, and seventh authors: USDA-ARS Grape Genetics Research Unit, Geneva, NY 14456; and fifth author: New York State Agricultural Experiment Station, Horticulture Department, Geneva, NY 14456. Current address of F. Gabler: California Table Grape Commission, Fresno, CA 93711. Accepted for publication 15 November 2010.

\begin{abstract}
Ramming, D. W., Gabler, F., Smilanick, J., Cadle-Davidson, M., Barba, P., Mahanil, S., and Cadle-Davidson, L. 2011. A single dominant locus, Ren4, confers rapid non-race-specific resistance to grapevine powdery mildew. Phytopathology 101:502-508.

In the present study we screened the progeny of Vitis vinifera $\times V$. romanetii populations segregating for resistance to powdery mildew and determined the presence of a single, dominant locus, Ren4, conferring rapid and extreme resistance to the grapevine powdery mildew fungus Erysiphe necator. In each of nine Ren4 pseudo-backcross $2\left(\mathrm{pBC}_{2}\right)$ and $\mathrm{pBC}_{3}$ populations (1,030 progeny), resistance fit a $1: 1$ segregation ratio and overall segregated as 543 resistant progeny to 487 susceptible. In fullsib progeny, microscopic observations revealed the reduction of penetration success rate (as indicated by the emergence of secondary hyphae)

Ren4 $\mathrm{pBC}_{2}$ population 03-3004 screened using natural infection in a California vineyard and greenhouse and using artificial inoculation of an aggressive New York isolate were fully consistent among all three pathogen sources and environments. From 2006 to 2010, Ren4 pBC $_{2}$ and $\mathrm{pBC}_{3}$ vines were continuously screened in California and New York (in the center of diversity for E. necator), and no sporulating colonies were observed. For population 03-3004, severity ratings on leaves, shoots, berries, and rachises were highly correlated $\left(R^{2}=0.875\right.$ to 0.996$)$ in the vineyard. Together, these data document a powdery mildew resistance mechanism not previously described in the Vitaceae or elsewhere, in which a dominantly inherited resistance prevents hyphal emergence and is non-race-specific and tissue-independent. In addition to its role in breeding for durable resistance, Ren4 may provide mechanistic insights into the early events that enable powdery mildew infection.
\end{abstract} from $86 \%$ in susceptible progeny to below $10 \%$ in resistant progeny. Similarly, extreme differences were seen macroscopically. Ratings for
Additional keywords: Mlg, PAMP-triggered immunity, Uncinula necator.
Powdery mildews are epiphytic pathogens of nearly all crop plants. Conidia landing on susceptible host tissues will germinate, form an appressorium for penetrating the cuticle and cell wall, and then form a primary haustorium inside a plant epidermal cell. If successful in evading host defenses, a secondary hypha will grow superficially, forming additional appressoria and haustoria as it extends and branches to colonize the plant surface. Being a multicyclic disease, this colonization can rapidly lead to an epiphytotic of massive proportions. Since all widely planted Vitis vinifera grape cultivars are susceptible to the powdery mildew fungus Erysiphe necator (syn. Uncinula necator), grape growers in the United States routinely apply 30 million pounds of sulfur every year in addition to chemicals with greater specificity to manage powdery mildew (30). Thus, grape cultivars with powdery mildew resistance would represent a significant financial and environmental improvement over their widely planted susceptible counterparts.

The lifecycle of powdery mildews can be disrupted by physical barriers as well as active strategies known as PAMP-triggered immunity (PTI) and effecter-triggered immunity (ETI) mounted

Corresponding author: L. Cadle-Davidson;

E-mail address: Lance.CadleDavidson@ars.usda.gov

* The $e$-Xtra logo stands for "electronic extra" and indicates that Figures 1 and 3 appear in color online.

doi:10.1094/PHYTO-09-10-0237

This article is in the public domain and not copyrightable. It may be freely reprinted with customary crediting of the source. The American Phytopathological Society, 2011 by nonhost or host plants, respectively $(19,23)$. PTI follows host recognition of broadly conserved pathogen associated molecular patterns (PAMPs), which are microbial products, such as chitin. Against powdery mildews, PTI reduces the incidence of primary haustorium formation and is exemplified by nonhost resistance, in which host-specific powdery mildews on nonhost plants can only germinate to form an appressorium and rarely develop further. ETI encompasses the resistance responses typical of most single, dominant resistance genes to-date in that it relies on the perception of a pathogen effector by a host receptor, typically a nucleotide binding leucine-rich repeat (NB-LRR) $R$-gene. As a result, ETI acts after formation of the haustorial feeding structure and secretion of effector proteins into the host epidermal cell, enabling some degree of hyphal growth, ranging from a single cell to a colony with trailing host necrosis (19). ETI is often overcome by the deletion or mutation of a single effector.

The inheritance, durability, and mechanisms of resistance to powdery mildew have been widely studied in barley, and the resultant data support PTI and ETI hypotheses $(26,29)$. The recessively inherited resistance gene mlo confers a prehaustorial, non-race-specific resistance and is one of the primary models for PTI and nonhost resistance. mlo resistance is used in over $50 \%$ of barley acreage and has remained durable since first reported in 1942 - exceptional in powdery mildew resistance (20). Mlg is a dominant resistance gene that also confers a prehaustorial penetration resistance but is race-specific (15). This suggests either that some effectors are secreted prior to haustorial formation, as in ETI resistance, or that isolates of the pathogen Blumeria graminis f. sp. hordeii are differential in the production of PAMPs 
that are recognized in $\mathrm{Mlg}$ PTI resistance. Other resistance genes in barley include Mla genes typical of posthaustorial gene-forgene resistance (28) and partial resistance genes that reduce penetration success in older leaves (5).

Genetic characterization and breeding for fungal resistance in Vitis lag behind those in barley due to negative fruit quality characteristics associated with resistance sources and long selection cycles necessary for grape breeding $(7,12,31)$. While not as data-rich as the barley pathosystems, resistance to powdery mildew in grapevine is being addressed through the identification of novel resistances, their mechanisms, and evaluation of their potential durability in the field. The Runl gene confers an ETI hypersensitive resistance phenotype that has been introgressed from the muscadine grape species $V$. rotundifolia into $V$. vinifera in a large $(\approx 1 \mathrm{Mb})$ chromatin block with suppressed recombination spanning two NB-LRR multigene families (2). While this locus shows promise for typical dominant $R$-genes, its incorporation into grape cultivars using traditional methods may be difficult because of linkage drag associated with the recombination-suppressed block of muscadine chromatin surrounding the resistance gene(s).

Although minor quantitative variation in the degree of susceptibility of $V$. vinifera cultivars has been documented (22), the species had been considered to be universally susceptible to powdery mildew. However, the first case of qualitative resistance (Ren1) was recently reported in the Central Asian V. vinifera cultivar Kishmish vatkana and manifests as a lack of macroscopic symptoms. Microscopically, however, a cell-death response occurs on a much slower timeframe that Runl-mediated HR and hyphal growth is merely slowed, not stopped in resistant individuals (16). Characterized as a single, dominant resistance gene, Renl has been localized to a region of the genome containing NB-LRR sequences, which is in keeping with its post-haustorial ETI resistance phenotype.

Evidence exists for the presence of grape powdery mildew races (13) and this being the case, resistance genes exhibiting ETI are likely to be overcome within a few years of deployment $(14,19)$. Consequently, both Renl and Runl may be of short-lived utility given their probable modes of action. While several Mlo orthologues have been identified in $V$. vinifera and may provide durable resistance, natural mlo-based resistance has not been identified in grapevine, and engineered cultivars may be many years away. Quantitative trait loci resistances such as Ren2 and Ren3 $(7,33)$ found in North American (NA) germplasm may hold promise for durability of at least partial resistance. However, interspecific hybrids are associated with potentially negative fruit quality characters, and none other than Runl has been cloned to date, thus keeping negative linkage disruption reliant on traditional breeding methods, large population sizes, and years of evaluation.

Given these challenges to effective powdery mildew resistance using known resistance sources, a relatively untapped Asian germplasm pool may offer some promise. Powdery mildew resistance has been identified in thirteen different Asian Vitis species
$(31,32)$. In general, no Asian species proved to be as highly resistant as NA species, yet there was significant variation within species. These studies reported slightly differing resistance findings due to differences in germplasm screened; however, both concluded that $V$. romanetii and the closely related $V$. davidii should be of considerable value for the introgression of powdery mildew resistance into $V$. vinifera $(31,32)$.

In the present study we screened the progeny of $V$. vinifera $\times V$. romanetii pseudo- (or modified-) backcross (pBC) populations segregating for resistance to powdery mildew and determined the presence of a single, dominant locus conferring extreme resistance that prevents emergence of secondary hyphae. Both the resistance source and the resistance phenotype identified here are novel in the Vitaceae and thus we name this resistance locus resistance to Erysiphe necator 4 (Ren4).

\section{MATERIALS AND METHODS}

Germplasm. $V$. romanetii ' $\mathrm{C} 166-026$ ' was obtained from the USDA-ARS repository in Davis, CA. A segregating $\mathrm{pBC}_{2}$ population 03-3004 was generated $(n=57)$, as described in Tables 1 and 2, and was established in the greenhouse. For each segregant, 14 dormant cuttings were taken with the goal of obtaining seven healthy plants: three plants for greenhouse evaluation; two for microscopy and laboratory evaluation; and two for field planting. Cuttings were rooted by dipping in Hormex No. 8 rooting powder (Brooker Corp., Chatsworth, CA) and sticking them in sand over bottom heat of $26^{\circ} \mathrm{C}$. When roots were 2 to $5 \mathrm{~cm}$ long, plants were potted, staked, and trained. As part of the breeding program, seven additional $\mathrm{pBC}_{2}$ populations and one $\mathrm{pBC}_{3}$ population were developed by cross-hybridizing related, resistant progeny to $V$. vinifera breeding lines (Table 2).

Greenhouse disease evaluation. Selections were screened for resistance to powdery mildew as young vines in greenhouses maintained at the USDA-ARS San Joaquin Valley Agricultural Sciences Center (Parlier, CA). Disease incidence at this age can predict the future incidence and severity of mildew infections on mature vines in the vineyard (22). Dormant grapevine cuttings taken in January 2006 were rooted and established in the greenhouse in February. Greenhouse vines that were several months to 1 year old were grown in $6 \mathrm{~cm}$ square $\times 18 \mathrm{~cm}$ tall Anderson pots (Anderson Die and Manufacturing, Portland, OR). Two powdery mildew susceptible $V$. vinifera 'Ruby Seedless' vines were placed in the middle of each tray containing 13 test vines to provide natural inoculum source for the test vines. Greenhouse powdery mildew assessments were conducted on two vine plots and evaluated for foliar disease incidence (percentage of leaves that exhibited powdery mildew symptoms) and disease severity, or coverage (percent leaf area infected). Symptoms were evaluated when $70 \%$ of susceptible control 'Ruby Seedless' leaves exhibited sporulating colonies. After the first evaluation in September 2006, the epidemic was allowed to progress further for a second evaluation in November 2006. The presence of mycelia was confirmed by microscopy. Incidence and severity scores were averaged and

TABLE 1. Pedigree of parents developed in this study of Ren4 resistance to Erysiphe necator ${ }^{\text {a }}$

\begin{tabular}{|c|c|c|c|}
\hline Generation $^{\mathrm{b}}$ & Female & Male & Resistant progeny \\
\hline F1 & C166-026 & $V$. vinifera & $B 36-44^{*}$ and $B 36-45^{*}$ \\
\hline pBC1 & Raisin de Palestine & B36-45* & $C 87-14$ and $C 87-41^{*}$ \\
\hline pBC1 & Rangspray & $B 36-45 *$ & $C 87-106^{*}$ \\
\hline $\mathrm{pBC} 2$ & $\mathrm{C} 70-76^{*}$ & C87-106* & $Y 313-137 *$ \\
\hline
\end{tabular}

${ }^{a}$ Resistant individuals are denoted in bold italics and seedless individuals are denoted with an asterisk $(*)$. Resistant progeny listed here were selected as parents (here or Table 2) based on lack of powdery mildew symptoms in the field and other positive traits under selection in the breeding program, including seedlessness and fruit quality traits.

${ }^{\mathrm{b}}$ The F1 cross was made by D. Cain with a Vitis vinifera breeding selection while at Sun World (Bakersfield, CA). pBC $=$ pseudo-backcross to a V. vinifera genotype. 
categorized as follows: resistant (R) 0 to $20 \%$; moderate (M) 21 to $40 \%$; and susceptible (S) 41 to $100 \%$.

A similar approach was used to screen for resistance on young vines in greenhouses at the USDA-ARS Grape Genetics Research Unit (Geneva, NY). Seed of population 07-3553 were germinated in December 2007 and maintained in $8 \mathrm{~cm}$ square $\times 8 \mathrm{~cm}$ tall pots (T.O. Plastics, Clearwater, MN). Ratings were recorded for foliar disease incidence and disease severity when more than $70 \%$ of leaves on susceptible 'Chardonnay' seedlings exhibited sporulating colonies. After the first evaluation in August 2008, the epidemic was allowed to progress further for a second evaluation in September 2008. Due to the extreme phenotype of resistance, vines with any sporulating powdery mildew were rated as susceptible.

Vineyard disease evaluation. Plants were grown at USDA, ARS San Joaquin Valley Agricultural Sciences Center (latitude $36^{\circ} 81^{\prime} \mathrm{N}$ : longitude $119^{\circ} 72^{\prime} \mathrm{W}$ ). The soil is a fine sandy loam and the vines were drip-irrigated. Vines were grown on their own roots at $4 \mathrm{~m} \times 0.5 \mathrm{~m}$ spacing, using a single T-trellis with a $0.75 \mathrm{~m}$ cross-arm on a $2 \mathrm{~m}$ stake and were cane pruned. No fungicides were applied. 'Ruby Seedless' plants were interplanted every 15 th vine as an inoculum source and to check for the amount of natural powdery mildew infection. Mildew assessments were performed between July and October for 3 years after the plants started fruiting in their third leaf. Disease severity was evaluated on leaf, shoot, rachis, and berry in order to determine tissue specificity of the resistance. Ratings on each tissue were recorded separately based on visual observation $(1=$ no infection $[\mathrm{R}]$; $2=$ very few small colonies; $3=<50 \%$ coverage; $4=>50 \%$ coverage $[\mathrm{S}])$.

Laboratory disease evaluation. Detached leaves were collected from disease-free potted vines on 12 September 2006, from the USDA, Parlier, CA greenhouse. Up to eight leaves per genotype were collected: the fourth fully expanded leaf and a mature leaf, from two replicate shoots per vine and from two replicate vines per genotype. The leaves were stacked in a standardized order, stored in sealed bags at $4^{\circ} \mathrm{C}$, and shipped on ice overnight to Geneva, NY. Upon receipt, leaves from a single vine were placed into a labeled, flexible plastic compact disk (CD) sleeve that had nine holes punched into it to facilitate wetting during subsequent leaf sterilization and washing. Leaves in CD sleeves were surface sterilized by submersion into calcium hypochlorite $(0.88 \mathrm{~g} / \mathrm{liter})$ for $2 \mathrm{~min}$ with agitation and then washed three times in sterile distilled water for $5 \mathrm{~min}$ each. The leaves were removed from each $\mathrm{CD}$ sleeve and plated adaxial side up onto petri dishes $(100 \times 15 \mathrm{~mm})$ containing $18 \mathrm{ml}$ of $1 \%$ water agar amended with $0.01 \mathrm{~g} /$ liter natamycin (Haorui Pharma-Chem, Edison, NJ) to prevent growth of fungal contaminants on the agar. Residual water was evaporated by removing the petri dish cover in a sterile laminar flow hood. After preparation of a complete batch, inocu- lation was conducted using E. necator isolate 10-18-1 collected from a 'Chardonnay' plant in Dresden, NY in 2003 (4). Spore suspensions were made by shaking conidiating leaves in $40 \mathrm{ml}$ of distilled water with $0.001 \%$ Tween 20 (Sigma-Aldrich, St. Louis, $\mathrm{MO}$ ), and the concentration was adjusted to $5 \times 10^{4}$ conidia/ml using a hemacytometer. Leaves were inoculated with approximately $0.5 \mathrm{ml}$ of the spore suspension using a Preval paint sprayer (Coal City, IL) and then placed into a $20 \pm 2^{\circ} \mathrm{C}$ growth chamber with $12 \mathrm{~h}$ photoperiod. Coverage was rated at 21 days postinoculation as the percentage of leaf area with powdery mildew mycelia. Due to the extreme phenotype of resistance, any colonies observed were interpreted as indicative of susceptibility.

Coomassie staining. Two susceptible genotypes ( $V$. vinifera 'Riesling' and susceptible breeding progeny Y553-50) and two resistant breeding progeny (Y553-20 and Y553-27) were used. Y553 progeny are full siblings from population 07-3553. The third and fourth youngest leaves were detached, sterilized as described above, and placed in 1\% agar (Acros, Geel, Belgium) for all assays. Leaves with actively sporulating colonies were used for inoculation by touching sporulating colonies directly to the leaf to be inoculated. Plates containing inoculated leaves were incubated at $20^{\circ} \mathrm{C}$ for 3 days. Four disks were collected from each leaf for staining with Coomassie blue (adapted from Doster and Schnathorst [8]), and the experiment was repeated twice. Leaf disks $\left(1 \mathrm{~cm}^{2}\right)$ were collected using a cork borer and placed in a 24-well plate for clearing in 3:1, vol/vol, ethanol: acetic acid, changing the solution three to four times until the tissue was completely bleached and then transferred to $50 \%$ ethanol for long-term storage. The solution was briefly replaced with Coomassie stain (Coomassie Brilliant Blue R-250 [0.12 g/liter] [Sigma-Aldrich, St. Louis, MO] in 50\% [vol/vol] methanol, and $10 \%$ [vol/vol] glacial acetic acid) to stain the mycelium, rinsed with several water changes, and mounted for viewing on a microscope slide in $50 \%$ glycerol.

Categorization was determined as follows: random samples of at least 50 spores per leaf disk were observed with a compound light microscope and categorized as (i) germinated spore with an appressorium, (ii) germinated spore with a secondary hypha, or (iii) germinated spore with multiple or branching secondary hypha. Penetration was defined as the proportion of spores within categories (ii) and (iii), whereas microcolony formation was defined as the proportion of spores within category (iii). Proportion and confidence limits (95\%) of penetration and microcolony formation were determined using the method of Wilson (34).

Resistance gene characterization. Segregation ratios within each population were determined by pooling any classes with powdery mildew infection to give only two phenotypic groups because only $0.05 \%$ of the progeny were rated intermediate. Since powdery mildew resistance is rare in $V$. vinifera (fewer than $0.1 \%$

TABLE 2. Powdery mildew resistance segregation ratios for Ren4 crosses screened in Parlier, CA or Geneva, NY greenhouses

\begin{tabular}{|c|c|c|c|c|c|}
\hline \multirow[b]{2}{*}{ Population } & \multirow[b]{2}{*}{ Generation $^{\mathrm{a}}$} & \multirow[b]{2}{*}{ Female $^{b}$} & \multirow[b]{2}{*}{ Male $^{b}$} & \multicolumn{2}{|c|}{ Severity ratings ${ }^{c}$} \\
\hline & & & & $\mathrm{R}$ & $\mathrm{S}$ \\
\hline 03-3004 & $\mathrm{pBC} 2$ & $C 87-41 *$ & B $70-57 *$ & 38 & 19 \\
\hline 07-3007 & $\mathrm{pBC} 2$ & $C 87-41 *$ & C58-37* & 113 & 114 \\
\hline 07-3008 & $\mathrm{pBC} 2$ & $C 87-41 *$ & A $85-40 *$ & 99 & 71 \\
\hline $07-3051$ & $\mathrm{pBC} 2$ & $C 87-106^{*}$ & B82-43* & 32 & 18 \\
\hline 07-3052 & $\mathrm{pBC} 2$ & $C 87-106^{*}$ & A50-33* & 45 & 46 \\
\hline $07-3053$ & $\mathrm{pBC} 3$ & B82-43* & Y313-137* & 57 & 55 \\
\hline $07-3054$ & $\mathrm{pBC} 2$ & B82-43* & $C 87-106^{*}$ & 28 & 29 \\
\hline $07-3056$ & $\mathrm{pBC} 2$ & B82-43* & $B 88-69 *$ & 40 & 41 \\
\hline \multirow[t]{2}{*}{$07-3553$} & $\mathrm{pBC} 2$ & C87-14 & B82-43* & 91 & 94 \\
\hline & & & Total & 543 & 487 \\
\hline
\end{tabular}

${ }^{\mathrm{a}} \mathrm{pBC}=$ pseudo-backcross to a Vitis vinifera genotype.

${ }^{\mathrm{b}}$ Resistant individuals are denoted in bold italics and seedless individuals are denoted with an asterisk (*).

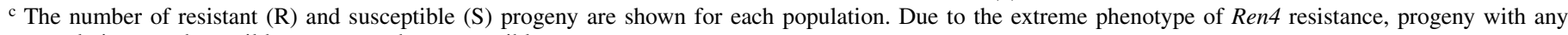
sporulating powdery mildew were rated as susceptible. 
of known cultivars), susceptible parents are assumed to be homozygous recessive (rr) at resistance loci. Taking into account the high heterozygosity of Vitis spp. and that resistance segregated in all crosses, the resistant parent in each cross is assumed to be heterozygous $(\mathrm{Rr})$ for at least one resistance locus. To determine the number of genes segregating in a given population, phenotypic classes were tested with a $\chi^{2}$ goodness of fit test against predicted ratios (i.e., 1R:1S single gene; 3R:1S two genes; etc.).

\section{RESULTS}

Progeny of the segregating population 03-3004 were either highly resistant or highly susceptible to powdery mildew, a result that was consistent between laboratory, greenhouse, and field disease screens (Table 3). Leaves of all resistant progeny had no macroscopically visible colonies, whereas leaves of sensitive progeny were completely covered with sporulating colonies (Fig. 1). Based on the above assumptions for the parental genotypes

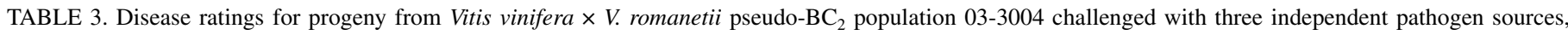
under greenhouse, field, or laboratory conditions

\begin{tabular}{|c|c|c|c|c|c|c|c|c|c|}
\hline \multirow[b]{2}{*}{ Segregant } & \multicolumn{2}{|c|}{ CA greenhouse } & \multicolumn{5}{|c|}{ CA vineyard } & \multicolumn{2}{|c|}{ NY detached leaf } \\
\hline & Leaf index $(\%)^{\mathrm{a}}$ & Rating & Leaf index ${ }^{b}$ & Rating & Shoot index & Rachis index & Berry index & Leaf coverage $(\%)^{\mathrm{c}}$ & Rating \\
\hline Y315-55 & 0 & $\mathrm{R}$ & 1 & $\mathrm{R}$ & 1 & 1 & 1 & 0 & $\mathrm{R}$ \\
\hline Y315-56 & 0 & $\mathrm{R}$ & 1 & $\mathrm{R}$ & 1 & 1 & 1 & 0 & $\mathrm{R}$ \\
\hline Y315-57 & 0 & $\mathrm{R}$ & 1 & $\mathrm{R}$ & 1 & - & - & 0 & $\mathrm{R}$ \\
\hline Y315-58 & 0 & $\mathrm{R}$ & 1 & $\mathrm{R}$ & 1 & 1 & 1 & 0 & $\mathrm{R}$ \\
\hline Y315-61 & 0 & $\mathrm{R}$ & 1 & $\mathrm{R}$ & 1 & - & - & 0 & $\mathrm{R}$ \\
\hline Y315-62 & 0 & $\mathrm{R}$ & 1 & $\mathrm{R}$ & 1 & - & - & 0 & $\mathrm{R}$ \\
\hline Y315-63 & 0 & $\mathrm{R}$ & 1 & $\mathrm{R}$ & 1 & 1 & 1 & 0 & $\mathrm{R}$ \\
\hline Y315-64 & 0 & $\mathrm{R}$ & 1 & $\mathrm{R}$ & 1 & 1 & 1 & 0 & $\mathrm{R}$ \\
\hline Y315-67 & 0 & $\mathrm{R}$ & 1 & $\mathrm{R}$ & 1 & - & - & 0 & $\mathrm{R}$ \\
\hline Y315-70 & 0 & $\mathrm{R}$ & 1 & $\mathrm{R}$ & 1 & 1 & 1 & 0 & $\mathrm{R}$ \\
\hline Y315-71 & 0 & $\mathrm{R}$ & 1 & $\mathrm{R}$ & 1 & - & - & 0 & $\mathrm{R}$ \\
\hline Y315-72 & 0 & $\mathrm{R}$ & 1 & $\mathrm{R}$ & 1 & 1 & 1 & 0 & $\mathrm{R}$ \\
\hline Y315-73 & 0 & $\mathrm{R}$ & 1 & $\mathrm{R}$ & 1 & - & - & 0 & $\mathrm{R}$ \\
\hline Y315-74 & 0 & $\mathrm{R}$ & 1 & $\mathrm{R}$ & 1 & - & - & 0 & $\mathrm{R}$ \\
\hline Y315-76 & 0 & $\mathrm{R}$ & 1 & $\mathrm{R}$ & 1 & - & - & 0 & $\mathrm{R}$ \\
\hline Y315-77 & 0 & $\mathrm{R}$ & 1 & $\mathrm{R}$ & 1 & - & - & 0 & $\mathrm{R}$ \\
\hline Y315-78 & 0 & $\mathrm{R}$ & 1 & $\mathrm{R}$ & 1 & - & - & 0 & $\mathrm{R}$ \\
\hline Y315-79 & 0 & $\mathrm{R}$ & 1 & $\mathrm{R}$ & 1 & - & - & 0 & $\mathrm{R}$ \\
\hline Y315-80 & 0 & $\mathrm{R}$ & 1 & $\mathrm{R}$ & 1 & - & - & 0 & $\mathrm{R}$ \\
\hline Y315-81 & 0 & $\mathrm{R}$ & 1 & $\mathrm{R}$ & 1 & - & - & 0 & $\mathrm{R}$ \\
\hline Y315-82 & 0 & $\mathrm{R}$ & 1 & $\mathrm{R}$ & 1 & - & - & 0 & $\mathrm{R}$ \\
\hline Y315-83 & 0 & $\mathrm{R}$ & 1 & $\mathrm{R}$ & 1 & 1 & 1 & 0 & $\mathrm{R}$ \\
\hline Y315-84 & 0 & $\mathrm{R}$ & 1 & $\mathrm{R}$ & 1 & - & - & 0 & $\mathrm{R}$ \\
\hline Y315-85 & 0 & $\mathrm{R}$ & 1 & $\mathrm{R}$ & 1 & 1 & 1 & 0 & $\mathrm{R}$ \\
\hline Y315-86 & 0 & $\mathrm{R}$ & 1 & $\mathrm{R}$ & 1 & - & - & 0 & $\mathrm{R}$ \\
\hline Y315-87 & 0 & $\mathrm{R}$ & 1 & $\mathrm{R}$ & 1 & 1 & 1 & 0 & $\mathrm{R}$ \\
\hline Y315-88 & 0 & $\mathrm{R}$ & 1 & $\mathrm{R}$ & 1 & - & - & 0 & $\mathrm{R}$ \\
\hline Y315-89 & 0 & $\mathrm{R}$ & 1 & $\mathrm{R}$ & 1 & - & - & 0 & $\mathrm{R}$ \\
\hline Y315-90 & 0 & $\mathrm{R}$ & 1 & $\mathrm{R}$ & 1 & 1 & 1 & 0 & $\mathrm{R}$ \\
\hline Y315-91 & 0 & $\mathrm{R}$ & 1 & $\mathrm{R}$ & 1 & - & - & 0 & $\mathrm{R}$ \\
\hline Y315-92 & 0 & $\mathrm{R}$ & 1 & $\mathrm{R}$ & 1 & - & - & 0 & $\mathrm{R}$ \\
\hline Y315-94 & 0 & $\mathrm{R}$ & 1 & $\mathrm{R}$ & 1 & - & - & 0 & $\mathrm{R}$ \\
\hline Y315-97 & 0 & $\mathrm{R}$ & 1 & $\mathrm{R}$ & 1 & - & - & 0 & $\mathrm{R}$ \\
\hline Y315-98 & 0 & $\mathrm{R}$ & 1 & $\mathrm{R}$ & 1 & - & - & 0 & $\mathrm{R}$ \\
\hline Y315-99 & 0 & $\mathrm{R}$ & 1 & $\mathrm{R}$ & 1 & 1 & 1 & 0 & $\mathrm{R}$ \\
\hline Y315-93 & 0 & $\mathrm{R}$ & 1 & $\mathrm{R}$ & 1 & 1 & 1 & $*$ & $*$ \\
\hline Y315-95 & 0 & $\mathrm{R}$ & 1 & $\mathrm{R}$ & 1 & 2 & 1 & $*$ & $*$ \\
\hline Y315-96 & 0 & $\mathrm{R}$ & 1 & $\mathrm{R}$ & 1 & 1 & 1 & $*$ & $*$ \\
\hline Y315-65 & 95 & $S$ & 4 & $\mathrm{~S}$ & 4 & 4 & 2 & 100 & $\mathrm{~S}$ \\
\hline Y315-66 & 92 & $\mathrm{~S}$ & 4 & $\mathrm{~S}$ & 4 & - & - & 90 & $\mathrm{~S}$ \\
\hline Y315-68 & 98 & $S$ & 4 & $\mathrm{~S}$ & 4 & 4 & 3 & 100 & $\mathrm{~S}$ \\
\hline Y315-69 & 98 & $\mathrm{~S}$ & 4 & $\mathrm{~S}$ & 4 & - & - & 90 & $\mathrm{~S}$ \\
\hline Y315-75 & 50 & $\mathrm{~S}$ & 4 & $\mathrm{~S}$ & 4 & - & - & 90 & $\mathrm{~S}$ \\
\hline Y315-100 & 95 & $\mathrm{~S}$ & 4 & $\mathrm{~S}$ & 3 & 4 & 2 & 60 & $\mathrm{~S}$ \\
\hline Y315-101 & 96 & $\mathrm{~S}$ & 4 & $\mathrm{~S}$ & 4 & - & - & 50 & $\mathrm{~S}$ \\
\hline Y315-102 & 64 & $S$ & 4 & $\mathrm{~S}$ & 4 & - & - & 20 & $\mathrm{~S}$ \\
\hline Y315-109 & 97 & $S$ & 4 & $\mathrm{~S}$ & 4 & - & - & 20 & $\mathrm{~S}$ \\
\hline Y315-103 & 98 & $S$ & 4 & $\mathrm{~S}$ & 4 & 4 & 2 & $*$ & $*$ \\
\hline Y315-105 & 97 & $S$ & 4 & $\mathrm{~S}$ & 4 & 4 & 4 & $*$ & $*$ \\
\hline Y315-106 & 96 & $\mathrm{~S}$ & 4 & $\mathrm{~S}$ & 4 & - & - & $*$ & $*$ \\
\hline Y315-107 & 96 & $S$ & 4 & $\mathrm{~S}$ & 4 & 4 & 4 & $*$ & $*$ \\
\hline Y315-108 & 97 & $S$ & 4 & $\mathrm{~S}$ & 4 & 4 & 4 & $*$ & $*$ \\
\hline Y315-110 & 96 & $\mathrm{~S}$ & 4 & $\mathrm{~S}$ & 4 & 4 & 3 & $*$ & $*$ \\
\hline Y315-111 & 97 & $\mathrm{~S}$ & 4 & $\mathrm{~S}$ & 4 & - & - & $*$ & $*$ \\
\hline Y315-113 & 97 & $\mathrm{~S}$ & 4 & $\mathrm{~S}$ & 4 & - & - & $*$ & $*$ \\
\hline Y315-112 & 97 & $S$ & 4 & $\mathrm{~S}$ & 4 & - & - & nd & nd \\
\hline Y315-114 & 98 & $\mathrm{~S}$ & 4 & $\mathrm{~S}$ & 4 & - & - & nd & nd \\
\hline
\end{tabular}

${ }^{a}$ Mean disease rating (average of incidence and severity) in September 2006: 0 to $20=$ resistant (R), 41 to $100=$ susceptible (S).

b Vineyard rating: $1=$ no visible powdery mildew $(\mathrm{R}), 4=$ more than $50 \%$ coverage $(\mathrm{S})$.

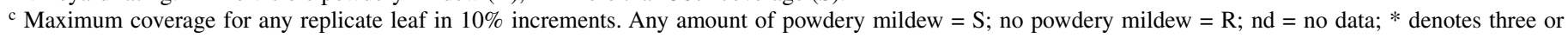
fewer replicates survived as detached leaves. 
used to generate these populations (heterozygous resistant $x$ homozygous susceptible), the lack of nonparental phenotypes among the progeny suggested the action of a single dominant resistance gene, a hypothesis not rejected by a $\chi^{2}$ goodness of fit test $(P=0.103)$. The hypothesis of a single dominant locus was independently supported by analysis across all nine related populations screened in $\mathrm{CA}$ and NY greenhouses (Table 2; $P=$ 0.596). Disease reactions among the different tissue types evaluated (leaf, shoot, rachis, and berry) were consistent (Table 3). Correlation coefficients between tissue type responses were at

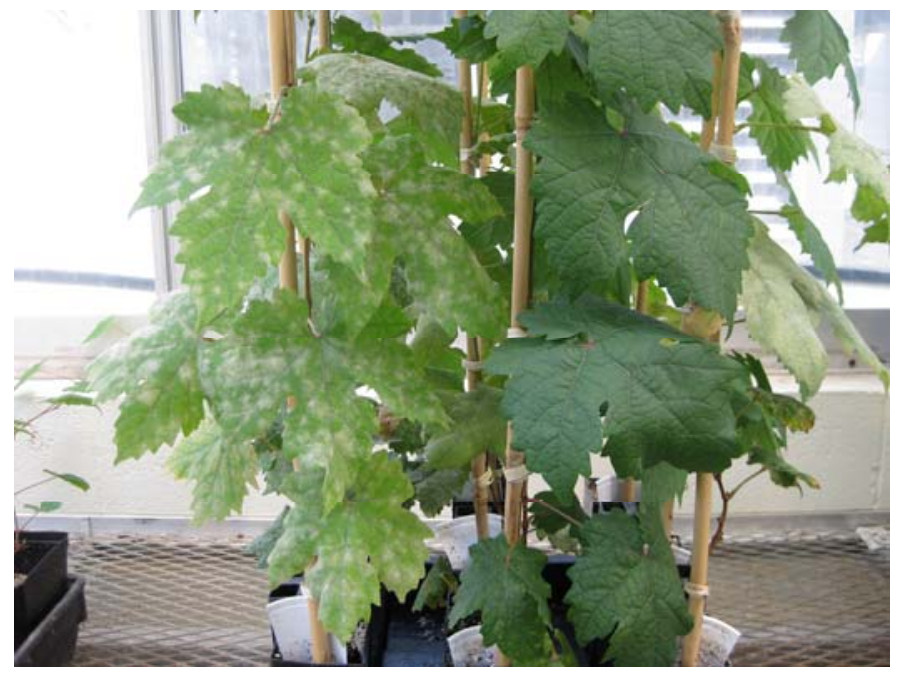

Fig. 1. Progeny of Vitis vinifera $\times V$. romanetii pseudo- $\mathrm{BC}_{2}$ population 03-3004 showing phenotypes of extreme susceptibility (left) or extreme resistance (right) characteristic of Ren4 resistance to Erysiphe necator.

TABLE 4. Correlation coefficients for powdery mildew disease ratings by tissue type in the Vitis vinifera $\times$ V. romanetii pseudo- $\mathrm{BC}_{2}$ population 03-3004 rated in a Parlier, CA vineyard

\begin{tabular}{lcccc}
\hline Correlations & Leaf & Shoot & Rachis & Berry \\
\hline Leaf & $\ldots$ & 0.996 & 0.990 & 0.883 \\
Shoot & $\ldots$ & $\ldots$ & 0.980 & 0.903 \\
Rachis & $\ldots$ & $\ldots$ & $\ldots$ & 0.875 \\
Berry & $\ldots$ & $\ldots$ & $\ldots$ & $\ldots$ \\
\hline
\end{tabular}

least 0.875 (berry versus rachis) and showed significant correlation $(P<0.0001)$ (Table 4). During vineyard, greenhouse, and laboratory evaluations from 2006 to 2010 , no sporulating colonies of $E$. necator were observed on resistant progeny.

As observed by light microscopy, resistant genotypes showed a marked reduction in powdery mildew penetration. A small proportion of germinated spores were able to penetrate leaf tissue and form secondary hypha (microcolonies) $-9.7 \%$ for Y 553-20 and $1.2 \%$ for Y553-27-compared with $86.4 \%$ penetration success in the susceptible full sib Y553-50 (Fig. 2). This difference is clearly seen by Coomassie staining in Figure 3, which also shows that few host cells reacted visibly at the infection site at 3 days postinoculation.

\section{DISCUSSION}

Our data demonstrate the presence of powdery mildew resistance in $V$. romanetii that is phenotypically novel both among Vitis spp. described thus far $(9,16)$ and among dominant powdery mildew resistance genes described in other plants $(5,15,28)$. The efficacy of resistance against different inoculum sources in CA field, CA greenhouse, NY detached leaf, and particularly NY greenhouse screens-in the center of origin for E. necator (3)over the past 5 years strongly suggest that this resistance is nonrace-specific (Table 3). Segregation analysis of our data across 1,030 progeny in nine independent populations clearly and repeatedly indicated the presence of a single dominant locus controlling this resistance. Both the resistance source and the resistance phenotype identified here are novel in the Vitaceae, and thus we name this resistance locus resistance to Erysiphe necator 4 (Ren4). Justification for naming the locus is further supported by studies mapping the locus to chromosome 18 (S. Mahanil, D. W. Ramming, and L. Cadle-Davidson, unpublished data), which has not previously been associated with powdery mildew resistance. The dominant, extreme, and rapid resistance seen in Ren4 (Figs. 2 and 3) appears to be unique among powdery mildew pathosystems and may be an example of nonhost resistance newly available for application and fundamental research.

Based on previous mapping studies in Vitis, at least four different powdery mildew resistance loci are known, having sources in several North American Vitis species and in central Asian V. vinifera $(1,6,7,12,25,33)$. Generally, the phenotypic data were collected based on a macroscopic rating scale that does not detail

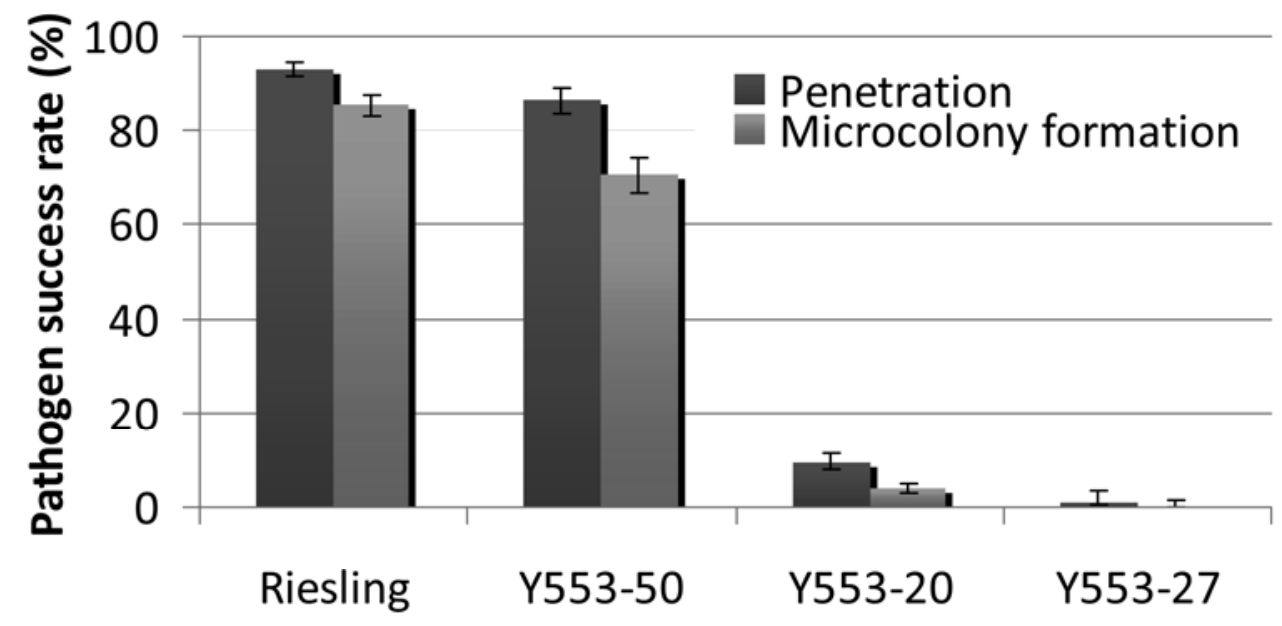

\section{Inoculated Seedling}

Fig. 2. Histogram showing percentage of successful penetration and microcolony formation by germinated conidia of Erysiphe necator. Vitis vinifera 'Riesling' and Y553-50 (a progeny from the V. vinifera $\times$ V. romanetii pseudo- $\mathrm{BC}_{2}$ population 07-3553) are susceptible controls. Y553-20 and Y553-27 are resistant progeny from 07-3553, therefore full sibs of Y553-50. The numbers of conidia counted to quantify penetration and microcolony success rate were: 1014 conidia for Riesling; 568 for Y553-50; 1053 for Y553-20; and 251 for Y553-27. Error bars represent 95\% confidence intervals. 
the tissue- or cell-level host responses to pathogen challenge. The few cases where microscopy data are available help to emphasize that the type of resistance we report here is novel. Ren1 resistance allows powdery mildew penetration by E. necator but slows subsequent hyphal growth (16). Similarly, Run1 resistance allows penetration and formation of secondary hyphae; however, programmed cell death of the penetrated epidermal cell rapidly halts elongation of secondary hyphae (9).

In the present study, successful penetration and secondary hyphal emergence on resistant genotypes was exceedingly rare, and this resistance response was not HR-dependent (Figs. 2 and 3 ), though infrequent host cell death was observed. Similarly, host cell death in mlo resistance may occur $30 \mathrm{~h}$ after penetration resistance successfully halts infection (26). Programmed cell death (PCD), whether a true $R$-gene-mediated, ETI response or not (29), typically requires penetration and haustorium formation by the fungus (19) and allows some secondary hyphal growth $(2,16)$. We did not directly observe a lack of haustoria, however extremely low incidence of growth beyond appressorium formation on resistant genotypes strongly suggests an absence of or nonfunctional haustoria formation (Figs. 2 and 3; Table 3). Thus, the resistance reported here appears to be due to a preformed barrier or PTI rather than ETI resistance. PTI resistance is the result of basal defenses recognizing PAMPs from nonadapted pathogens rather than the specific effectors of adapted pathogens $(19,23)$. The response includes the release of antimicrobial compounds, toxic aglycones, a build-up of cell wall components, or some combination of the three in the vicinity of an appressorium (attempted penetration) and results in failed penetration by the fungus (23).

Several characterized resistance genes from other species are known to confer PTI, but none display a dominant genetic action along with distinct resistant versus susceptible allelic phenotypes. The PEN1/ROR2, PEN2, and PEN3 alleles confer penetration resistance in Arabidopsis; however, their recessive alleles play active roles in ETI and PCD-mediated nonhost interactions, resulting in an intermediate resistance phenotype (26,36). pmr6, pmr4/gsl5, and cevl independently confer broad-spectrum powdery mildew resistance in Arabidopsis due to mutations in pectate lyase, cellulose synthase, and cellulose synthase isoform A3, respectively $(10,18,24)$. Mlo resistance results from mutations in a plant-specific seven transmembrane domain protein present in multigene families and orthologues of which have been shown to be conserved and confer resistance in many different plant species $(11,17,26,35)$. All of these genes confer complete or partial penetration resistance as recessive alleles and are associated with nonhost resistance.

Ren4 from $V$. romanetii is dominant yet seemingly provides nearly complete, non-race-specific resistance reminiscent of the nonhost resistance genes pmr6, pmr4/gsl5, cevl, and mlo. Evaluations of $V$. romanetii and closely related $V$. davidii germplasm in China reveal an astonishing level of resistance to powdery mildew $(31,32)$ for species that did not coevolve with E. necator $(21,27)$. Were it not for the dominant action of the gene identified here, these data taken together would support classification of Ren4 as a nonhost resistance gene. However, because not all accessions of $V$. romanetii are resistant to E. necator (32), by definition, Ren4 should not be considered a nonhost resistance gene (23). Further, without evidence of a specific PAMP receptor involved, we hesitate to categorize Ren4 resistance as PTI. As a gene without perfect analogy, Ren4 must for now be defined simply as conferring rapid non-race-specific resistance.

Only two preliminary screening studies have been performed in $V$. romanetii $(31,32)$ both of which have identified powdery mildew resistant accessions. There has been no report of allelism tests between resistant accessions, and considering the range of phenotypes reported, multiple resistance genes may be present (32). Wan and colleagues (31) identified downy mildew resistance in this species, which invites further resistance screening with additional pathogens.

The first $\mathrm{pBC}_{2}$ table and raisin grape selections with Ren4 resistance to powdery mildew were planted in production trials at USDA/ARS Parlier, CA in 2009 and 2010. The table grape selection in the trial has $12 / 16$ in. diameter berries that average $5.4 \mathrm{~g}$ with small aborted seeds the size of 'Thompson Seedless'. The five raisin selections in the trial have fruit quality rated as high as the best natural dry-on-the-vine selection with aborted seeds the size of Thompson Seedless. The source of powdery
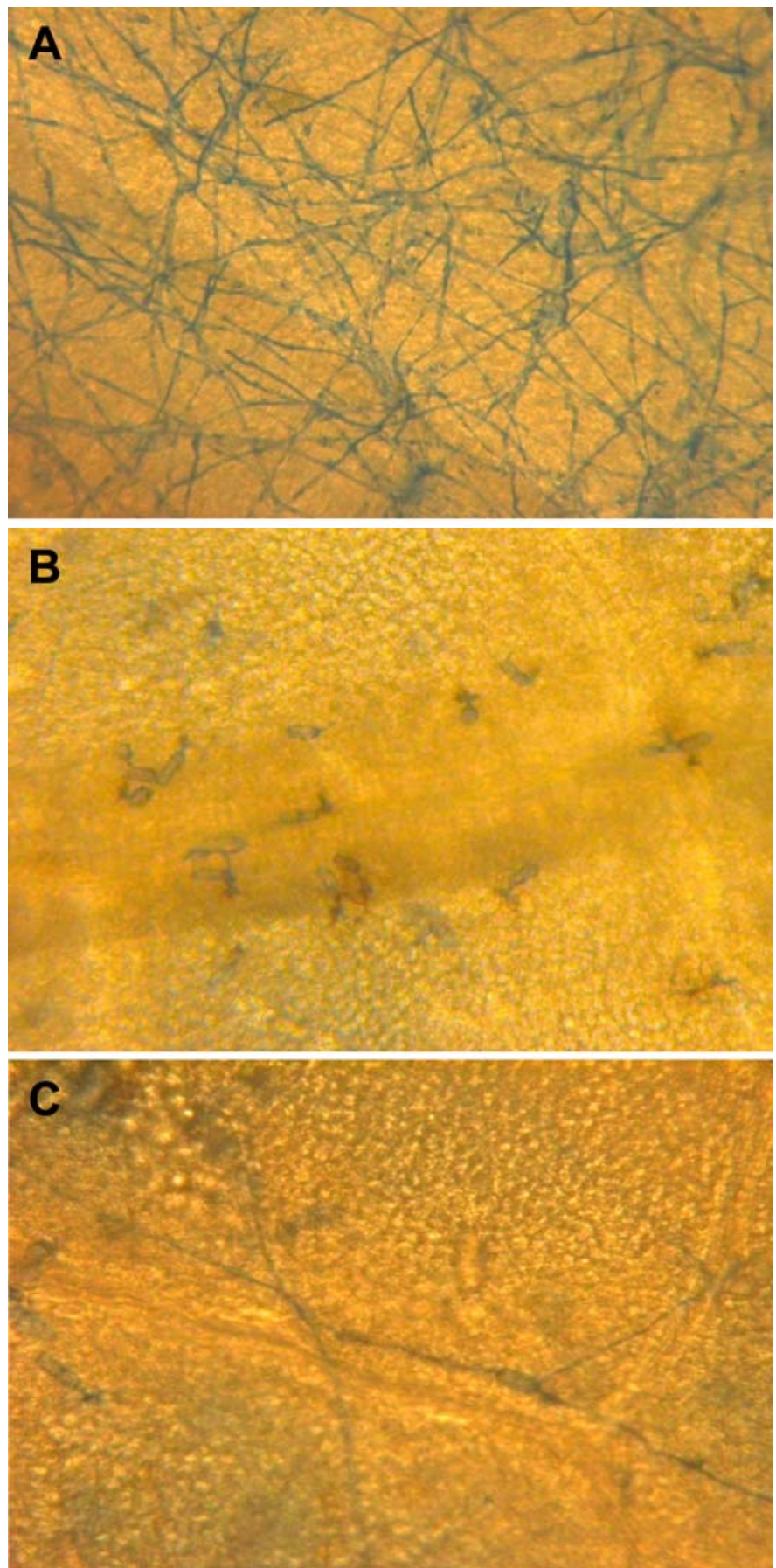

Fig. 3. Erysiphe necator development on leaves of a characteristic progeny $($ Y553-20) with Ren4 resistance from the Vitis vinifera $\times V$. romanetii pseudo$\mathrm{BC}_{2}$ population 07-3553. Coomassie blue staining of E. necator on cleared leaves shows A, complete susceptibility of $V$. vinifera 'Riesling' demonstrated by unrestricted hyphal growth and overlapping microcolonies; B, no penetration on Y553-20 as indicated by lack of secondary hyphal growth; and $\mathbf{C}$, rare instance of successful penetration and microcolony formation on otherwise resistant Y553-20. 
mildew resistance, C166-026, has small seeded berries, 8/16 in. diameter with black fruit, so significant improvement in fruit quality has already been achieved among these $\mathrm{pBC}_{2}$ progeny.

Resistance gene durability is critical for woody perennial crops such as grapevine. Unlike annual crops, grapevines are expected to be productive for at least 20 years-plenty of time for a pathogen to overcome ETI. This fact and the long generation time ( 3 to 5 years from seed to seed) underscore the need for broad and durable resistance when developing new grape cultivars. In this regard Ren 4 should be of importance in breeding for powdery mildew resistance in grapes, but at the same time the spectrum of resistance, potential durability of resistance, and protective management strategies deserve further investigation.

\section{ACKNOWLEDGMENTS}

This research was supported by the American Vineyard Foundation, California Table Grape Commission, California Raisin Marketing Board, Viticultural Consortium West, and the California Competitive Grants Program for Viticulture and Enology. We thank J. Barnard for discussions related to the statistical analyses presented here.

\section{LITERATURE CITED}

1. Akkurt, M., Welter, L., Maul, E., Topfer, R., and Zyprian, E. 2007. Development of SCAR markers linked to powdery mildew (Uncinula necator) resistance in grapevine (Vitis vinifera L. and Vitis sp.). Mol. Breed. 19:103-111.

2. Barker, C. L., Donald, T., Pauquet, J., Ratnaparkhe, M. B., Bouquet, A., Adam-Blondon, A. F., Thomas, M. R., and Dry, I. B. 2005. Genetic and physical mapping of the grapevine powdery mildew resistance gene, Run1, using a bacterial artificial chromosome library. Theor. Appl. Genet. 111:370-377.

3. Brewer, M. T., and Milgroom, M. G. 2010. Phylogeography and population structure of the grape powdery mildew fungus, Erysiphe necator, from diverse Vitis species. BMC Evol. Biol. 10:268.

4. Cadle-Davidson, L., Chicoine, D. R., and Consolie, N. H. 2010. Variation within and among Vitis species for foliar resistance to the powdery mildew pathogen Erysiphe necator. Plant Dis. 95:202-211.

5. Carver, T. L. W., and Thomas, B. J. 1990. Normal germling development by Erysiphe graminis on cereal leaves freed of epicuticular wax. Plant Pathol. 39:367-375.

6. Coleman, C., Copetti, D., Cipriani, G., Hoffman, S., Kozma, P., Kovacs, L., Morgante, M., Testolin, R., and Di Gaspero, G. 2009. The powdery mildew resistance gene REN1 co-segregates with an NBS-LRR gene cluster in two Central Asian grapevines. BMC Genet. 10:89.

7. Dalbo, M. A., Ye, G. N., Weeden, N. F., Wilcox, W. F., and Reisch, B. I. 2001. Marker-assisted selection for powdery mildew resistance in grapes. J. Am. Soc. Hortic. Sci. 126:83-89.

8. Doster, M. A., and Schnathorst, W. C. 1985. Effects of leaf maturity and cultivar resistance on development of the powdery mildew fungus on grapevines. Phytopathology 75:318-321.

9. Dry, I. B., Feechan, A., Anderson, C., Jermakow, A. M., Bouquet, A., Adam-Blondon, A. F., and Thomas, M. R. 2010. Molecular strategies to enhance the genetic resistance of grapevines to powdery mildew. Aust. J. Grape Wine R. 16:94-105.

10. Ellis, C., and Turner, J. G. 2001. The Arabidopsis mutant cev1 has constitutively active jasmonate and ethylene signal pathways and enhanced resistance to pathogens. Plant Cell 13:1025-1033.

11. Feechan, A., Jermakow, A. M., Torregrosa, L., Panstruga, R., and Dry, I. B. 2008. Identification of grapevine $M L O$ gene candidates involved in susceptibility to powdery mildew. Funct. Plant Biol. 35:1255-1266.

12. Fischer, B. M., Salakhutdinov, I., Akkurt, M., Eibach, R., Edwards, K. J., Topfer, R., and Zyprian, E. M. 2004. Quantitative trait locus analysis of fungal disease resistance factors on a molecular map of grapevine. Theor. Appl. Genet. 108:501-515.
13. Gadoury, D. M., and Pearson, R. C. 1991. Heterothallism and pathogenic specialization in Uncinula necator. Phytopathology 81:1287-1293.

14. Gohre, V., and Robatzek, S. 2008. Breaking the barriers: Microbial effector molecules subvert plant immunity. Annu. Rev. Phytopathol. 46:189-215.

15. Gorg, R., Hollricher, K., and Schulze-Lefert, P. 1993. Functional analysis and RFLP-mediated mapping of the $M l g$ resistance locus in barley. Plant J. 3:857-866.

16. Hoffmann, S., Di Gaspero, G., Kovacs, L., Howard, S., Kiss, E., Galbacs, Z., Testolin, R., and Kozma, P. 2008. Resistance to Erysiphe necator in the grapevine 'Kishmish vatkana' is controlled by a single locus through restriction of hyphal growth. Theor. Appl. Genet. 116:427-438.

17. Humphry, M., Consonni, C., and Panstruga, R. 2006. mlo-based powdery mildew immunity: Silver bullet or simply non-host resistance? Mol. Plant Pathol. 7:605-610.

18. Jacobs, A. K., Lipka, V., Burton, R. A., Panstruga, R., Strizhov, N., Schulze-Lefert, P., and Fincher, G. B. 2003. An Arabidopsis callose synthase, GSL5, is required for wound and papillary callose formation. Plant Cell 15:2503-2513.

19. Jones, J. D. G., and Dangl, J. L. 2006. The plant immune system. Nature 444:323-329.

20. Jorgensen, J. H. 1992. Discovery, characterization and exploitation of $m l o$ powdery mildew resistance in barley. Euphytica 63(1-2):141-152.

21. Kuo, K.-C., Yee, C.-L., Kau, C.-W., and Leu, L.-S. 1989. Cleistothecia of Uncinula necator (Schw) Burr. in Taiwan. Trans. Myc. Soc. R.O.C. 4:53-58.

22. Li, H. 1993. Studies on the resistance of grapevine to powdery mildew. Plant Pathol. 42:792-796.

23. Lipka, U., Fuchs, R., and Lipka, V. 2008. Arabidopsis non-host resistance to powdery mildews. Curr. Opin. Plant Biol. 11:404-411.

24. Nishimura, M. T., Stein, M., Hou, B. H., Vogel, J. P., Edwards, H., and Somerville, S. C. 2003. Loss of a callose synthase results in salicylic aciddependent disease resistance. Science 301:969-972.

25. Pauquet, J., Bouquet, A., This, P., and Adam-Blondon, A. F. 2001. Establishment of a local map of AFLP markers around the powdery mildew resistance gene Runl in grapevine and assessment of their usefulness for marker assisted selection. Theor. Appl. Genet. 103:1201-1210.

26. Piffanelli, P., Devoto, A., and Schulze-Lefert, P. 1999. Defence signaling pathways in cereals. Curr. Opin. Plant Biol. 2:295-300.

27. Sawada, K. 1914. The classification of Erysiphaceae based on the conidial stages. Formosan Agric. Exp. Stn. Spec. Rep. 9:67-68.

28. Schiffer, R., Gorg, R., Jarosch, B., Beckhove, U., Bahrenberg, G., Kogel, K. H., and Schulze-Lefert, P. 1997. Tissue dependence and differential cordycepin sensitivity of race-specific resistance responses in the barley powdery mildew interaction. Mol. Plant-Microbe Interact. 10:830-839.

29. Schulze-Lefert, P. 2004. Knocking on heaven's wall: Pathogenesis of and resistance to biotrophic fungi at the cell wall. Curr. Opin. Plant Biol. 7:377-383.

30. USDA-NASS. 2006. Agricultural Chemical Usage Fruit Summary. Published online by USDA-NASS at http://www.nass.usda.gov/.

31. Wan, Y. Z., Schwaninger, H., He, P. C., and Wang, Y. J. 2007. Comparison of resistance to powdery mildew and downy mildew in Chinese wild grapes. Vitis 46:132-136.

32. Wang, Y., Liu, Y., He, P., Chen, J., Lamikanra, O., and Lu, J. 1995. Evaluation of foliar resistance to Uncinula necator in Chinese wild Vitis species. Vitis 34:159-164.

33. Welter, L. J., Gokturk-Baydar, N., Akkurt, M., Maul, E., Eibach, R., Topfer, R., and Zyprian, E. M. 2007. Genetic mapping and localization of quantitative trait loci affecting fungal disease resistance and leaf morphology in grapevine (Vitis vinifera L.). Mol. Breed. 20:359-374.

34. Wilson, E. E. 1927. Effects of fungous extracts upon the initiation and growth of the perithecia of Venturia inaequalis (Cke.) Wint. in pure culture. Phytopathology 17:835-836.

35. Winterhagen, P., Howard, S. F., Qiu, W. P., and Kovacs, L. G. 2008. Transcriptional up-regulation of grapevine $M L O$ genes in response to powdery mildew infection. Am. J. Enol. Viticult. 59:159-168.

36. Zhang, Z. G., Feechan, A., Pedersen, C., Newman, M. A., Qiu, J. L., Olesen, K. L., and Thordal-Christensen, H. 2007. A SNARE-protein has opposing functions in penetration resistance and defense signaling pathways. Plant J. 49:302-312. 